\title{
Survival Motor Neuron Protein
}

National Cancer Institute

\section{Source}

National Cancer Institute. Survival Motor Neuron Protein. NCI Thesaurus. Code C127871.

Survival motor neuron protein (294 aa, $32 \mathrm{kDa}$ ) is encoded by the human SMN1 and SMN2 genes. This protein plays a role in the assembly of small nuclear ribonucleoproteins. 